DOI: 10.20472/IAC.2017.032.021

\author{
NODAR KILADZE \\ Ivane Javakhishvili Tbilisi State University, Georgia

\section{EVALUATING INFLATION TARGETING REGIME - CASE STUDY: GEORGIA}

\begin{abstract}
:
Inflation is an indicator used by economists to assess the economic performance of the country as it shows percentage growth of price level. High inflation means higher growth rate of prices which is bad for the economy and for the country mainly because of the reduction of average labor purchasing power, caused by stickiness of wages, which decreases economic welfare. Another important factor is divergence between the price levels of different goods and services. Zero lower bound inflation (or deflation) can also cause serious negative results such as output collapse in response to various shocks leading to economic stagnation and high rate of unemployment. Both too high and too low inflation are problem that should be solved by policymakers to achieve sustainable economic growth and long-run development of the country. Because of the above-mentioned reasons low and stable rate of inflation is to be considered the most efficient for reaching high rate of economic growth and development. This paper reviews mentioned problems and outlines why it is so crucial to have inflation rate at low level and why is it vital to keep it stable. Most of the countries desire to have their inflation rate at $2 \%$. Inflation targets mostly vary from 2 to $5 \%$ depending on the central bank and economic development of the country but with a long run inflation target of maximum $2-3 \%$.

The National Bank of Georgia adopted Inflation Targeting regime in 2009 while some economists had misconceptions and debates about this decision and some papers were criticizing Georgia for not being ready for this change yet mostly because of its institutional setup and imperfect monetary transmission mechanism (Billmeier \& Bakradze, 2007). The results of this adoption are reviewed in this paper by assessing economic performance during Monetary Targeting regime and comparing it to the period after Inflation Targeting regime. This paper uses price level stability comparison between these two periods as well as relative price variability among different commodity groups. The model investigates the relationship between inflation rate and the relative price variability and shows that adopting Inflation Targeting regime significantly improved economic performance of the country.
\end{abstract}

\title{
Keywords:
}

Inflation Targeting Regime, Monetary Targeting Regime, Monetary Policy, Central Banks

JEL Classification: E42, E31, E50 